\title{
The development of an Education Grand Rounds program at an academic health center
}

\author{
Melissa S. Medina1 ${ }^{\text {, Valerie N. Williams }}{ }^{2}$, Laura R. Fentem ${ }^{2}$ \\ ${ }^{1}$ The University of Oklahoma College of Pharmacy, USA \\ ${ }^{2}$ The College of Medicine at the University of Oklahoma Health Sciences Center, USA \\ Correspondence: Melissa S. Medina, University of Oklahoma College of Pharmacy, Oklahoma City, OK, USA \\ E-Mail: melissa-medina@ouhsc.edu
}

Accepted: May 07, 2010

\begin{abstract}
Objectives: Faculty in the health professions need to demonstrate teaching effectiveness and faculty development of teaching can help them achieve this expectation. While there are several development options, the utility of an Education Grand Rounds was explored. The objectives were to coordinate eight yearly sessions focused on six topic priorities, involve our main and distant campus and national presenters, deliver live sessions to the main and distant campus and video-capture sessions, and dedicate session time to active learning.

Methods: Education Grand Rounds was developed by faculty and administrative representatives from all six colleges on our two campuses and made available to all faculty at our academic health sciences center. Six sessions topics were prioritized: didactic and clinical teaching, education research, assessment/evaluation, education administration, and instructional technology.
\end{abstract}

Results: Over five years, eight active learning sessions a

year were delivered to the main and distant campuses emphasizing six prioritized teaching areas, included local and national presenters, with sixteen sessions videocaptured. On average monthly attendance was nineteen from the main and three from the distant campuses, representing five of six disciplines. The majority of attendees reported above/significantly above average satisfaction with the sessions.

Conclusions: Education Grand Rounds is a sustainable form of faculty development for health sciences center faculty located on two campuses. Future directions should assess the impact of topic sequencing presented in multiple modalities, synchronous versus asynchronous participation, and the types of active learning used on participants' teaching improvement and change as a result of the sessions.

Keywords: Interdisciplinary education, instructional design, pedagogy, faculty development, distance education

\section{Introduction}

Training clinical and basic science healthcare educators in teaching skills is important because although faculty are expected to teach effectively, the amount of formal training in teaching or assessment methods faculty receive prior to their first academic appointment is variable. ${ }^{1,2,3}$ Doctoral education emphasizes research and medical education emphasizes clinical skills, therefore, faculty development in teaching skills is needed to emphasize principles of effective teaching and promotion of student learning., ${ }^{4,5}$ Participation in faculty development programs to enhance these skills promotes desirable teaching behaviors. ${ }^{1,6}$ Despite the need for faculty development programs of this type, many programs are only offered sporadically. ${ }^{7}$ In order to offer consistent faculty development of teaching skills, the utility of a medical grand rounds structure was adopted. The concept of medical grand rounds emerged as a teaching exercise for physicians using a lecture based presentation with objectives about a medical topic intended to educate participants, showcase faculty role models and promote collegiality. ${ }^{8}$ This structure met our initial goals and therefore, medical grand rounds was explored as a means for faculty development at our Academic Health Center (AHC) for clinical and basic science faculty. Offering faculty development at an AHC, where effective teaching is extremely important, is complex due to the multiple disciplines present. This structure offered appeal since medical grand rounds are commonly offered on a monthly basis in many university hospital settings ${ }^{8}$ and in other healthcare 
disciplines as well. Our AHC's acceptance of the grand rounds model, coupled with the regularity of its offerings, led to the development of an Education Grand Rounds (EGR) program to address the campus' need for faculty development in teaching skills for our basic science and clinical faculty. Although individual colleges sponsor discipline specific faculty development programs and the university cosponsors a longitudinal faculty development program for early career faculty, EGR fits the niche that these programs do not fill because it is a short interdisciplinary program and is focused only on the education mission.

One instance of a Medical Education Grand Rounds (MEGR) program focused on teaching skills (versus medical topics) developed for basic science and clinical attendees was noted in literature and supported our plans to create EGR, but lacked sufficient details to provide guidance. ${ }^{9}$ The EGR program at the University of Oklahoma Health Sciences Center (HSC) was designed for faculty in all of our university's professional schools (i.e. medicine, pharmacy, nursing, allied health, public health, and dentistry). These schools are co-located on a main campus in Oklahoma City and five of the schools also have faculty at a distant campus in Tulsa.

\section{Education Grand Rounds Objectives}

1. Utilizing an interdisciplinary team approach, coordinate at least eight monthly education grand rounds that emphasize one of six prioritized topics.

2. Involve presenters from each of the colleges on the HSC main and distant campus with at least one presenter from each discipline and at least one national presenter a year to ensure broad and meaningful outreach to participants.

3. Deliver EGR to all colleges on the main and distant campus (documenting college and campus attendance/outreach) and video-capture presentations to allow for asynchronous viewing of sessions to allow for flexible faculty development.

4. Deliver at least one-third of the one hour presentation using active learning techniques to optimize audience learning and gather feedback from session participants about learning, skill and attitude outcomes, as well as quality of presentation to promote continuous quality improvement of EGR.

\section{Methods}

We first created an interdisciplinary team in June 2003 (Objective 1) that consisted of 14 members, most of whom had training, a degree, and/or interest in education. Specifically, a faculty representative from each of the six professional schools, two from the distant campus, and six campus and college administrators, constituted the initial EGR team. This team identified faculty development needs, outlined topics and presenters for the workshops, and scheduled monthly one-hour interactive (versus lecture only) workshops. While the EGR team volunteers have varied over the years, college, administrative and distant campus representation has been maintained. Once the team was established, they outlined six priorities for the EGR workshops and created a monthly schedule to address each of the six topics over the year. The six priorities were:

- didactic teaching

- experiential/clinical teaching

- education focused research/scholarship

- assessment/evaluation

- administrative education and

- teaching and assessment using technology

After the team established the topic priorities, they began identifying at least eight topics for the year (Objective 1). The team used the six priorities and specific topic identification began with discussion of what members perceived as the needs of faculty at their respective colleges. Because many of the EGR team members had faculty development roles at their college and were formally aware of faculty development needs related to teaching and learner assessment, identifying faculty needs was made easier. The team discussed possible themes for the program year based on educational or campus trends. Discussion concluded with a designated theme that addressed the six priorities through eight EGR sessions. Sessions were prioritized and scheduled and a list of potential topics for future sessions was maintained. Part of the session planning was also contingent on the identification (and availability) of potential local and national speakers who could address the development need (Objective 2). The EGR team was large enough to facilitate discussion of topics and potential speakers and the use of the six priorities and themes made the process intentional and focused on enhancing faculty development devoted to the teaching mission.

All presentations were scheduled for live connection between the Oklahoma City and Tulsa campuses (Objective 3). The team worked with the campus Television Services to digitally record the presentations. Once captured, the presentation and slides and handouts were placed on the EGR website (www.ouhsc.edu/egr) enabling faculty who missed the session to view it later. The team also explored the possibility of allowing access to a live session from a person's desk versus attending the presentation at the auditorium as an additional faculty development outreach option. In fall 2007, Television Services piloted the use of Mediasite from Sonic Foundry as a way to record and deliver EGR online. Once the proposed presenters and topics were confirmed, the EGR team created presentation guidelines for invited speakers to formally articulate the active learning expectations for the session (Objective 4). These presenter guidelines, which were posted to the EGR website, included presentation design standards of at least $1 / 3$ active learning/audience interaction of the total presentation, requests for detailed presentation objectives and description, and a presenter release to archive/post materi- 
als on the EGR website. Evaluation forms were created for every session (Objective 4) to assess the pre and post knowledge, skills and attitude related to the presentation objectives.

The team used the evaluation results for continuous quality improvement, to guide EGR planning and delivery, and to conduct audience needs assessments. Participants evaluated their satisfaction with the session, perceptions of learning outcomes at each session, intention to apply the information or seek more information on the topic, and attendee preference for future EGR topics. No individually identifying information was provided to the EGR team from the evaluation forms. EGR data were collected as part of a programmatic assessment and improvement process and Institutional Review Board approval was not sought for this data collection.

\section{Results}

\section{Objective 1}

Since June 2003, forty-three presentations were delivered for eight months/year for five years. Topics originated from the EGR team and emphasized the six main categories (see Table 1) described in Objective 1. The complete list of EGR topics/titles are in Table 2, revealing that the majority emphasized didactic teaching, such as writing objectives, team-based learning, learner preferences, documenting teaching efforts, and case/problem-based/group facilitating.

Table 1. Education grand rounds topics presented ( $N=43$ total presentations delivered from June 2003-May 2008)

\begin{tabular}{ccccccc}
\hline Didactic & Clinical & Technology & Research & Evaluation & Administrative \\
\hline 15 & 3 & 9 & 9 & 4 & 3 \\
\hline
\end{tabular}

Technology was frequently presented and included topics such as improving presentation graphics, working with Blackboard (a learning management system available to faculty), and using virtual reality, simulations and artificial intelligence to teach and assess student learning. Education research and the scholarship of teaching were regularly offered emphasizing the concept and benefits of the scholarship of teaching as well as methods for getting started in education research. College deans from the campus also delivered education administration presentations providing unique insight into their teaching philosophies (see Tables 1, 2, and 3). Teaching topics focused on specific disciplines were not offered, although during discussion of various topics college specific practices were cited as examples or were referenced during the sessions.

Popular topics were either repeated or a variation or extension of the topic was created. An annual report of EGR status was also completed and circulated to campus administration as a tool to document progress, afford input from senior academic administrators, and sustain support for this campus education initiative.

\section{Objective 2}

EGR presentations have been delivered by faculty from five of the six health professions colleges on campus and seven presentations were presented by interdisciplinary teams (see Tables 3 and 4). Presentations originated from the distant campus (Tulsa) four times, although the majority was delivered from the main campus (see Table 3). Starting in the third year of EGR (2006), national presenters delivered EGR twice a year, exceeding the original goal of once a year.

\section{Objective 3}

Forty of the forty-three EGR presentations were delivered to both the main and distant campuses. On three occasions, a face-to-face live interaction was deemed more appropriate than the distance education component: the education scholarship day and the two journal club sessions. Since part of EGR's goal was to increase intercampus discussion about education theory and practice, campus attendance was collected at every session. Average attendance over three academic years of 2005 to 2008 as of February 2008 was 22.4 for the main and distant campus $(\mathrm{SD}=11.60$, range $=8-49$ ) see Table 5. Attendance at the main campus was on average $19.3(\mathrm{SD}=10.4$, range $=8-41)$ and on the distant campus was on average $3.22(\mathrm{SD}=2.8$, range $=1-8)$. Overall every college on campus and three additional offices/departments had at least one person attend EGR on a monthly basis, with the exception of the Physician Assistant Program that had no identified attendees.

The third objective was also met by creating an EGR website to archive EGR presentation materials (videos, handouts, etc.) as well as other campus education initiatives, materials and tools. Twenty-five of the forty-three (58\%) presentations had handouts and/or slides or other related resources posted on the EGR website allowing asynchronous faculty viewing and flexible faculty development. Fourteen of the forty-three presentations (33\%) also included video archives of the presentation further adding to this flexibility. Starting in September 2007, through pilot testing, $100 \%$ of the presentations were video archived and posted on the EGR website. Table 6 reveals the number of people viewing the live presentation of EGR from their desks, the number of people watching the archive asynchronously and the percent of the archived presentation viewed.

\section{Objective 4}

The majority of presentations contained active learning components with most including audience discussion of the topic, while some utilized audience review, critique or refinement of sample materials or processes. However, no formal measures documenting the amount of active learning per session were performed nor were performancebased assessments used to capture the actual knowledge or skills participants gained in the sessions. Data from the pre and post EGR evaluations from September 2005 to June 2008 reflect $78.37 \%$ (range $=76.64-79.79$ ) of participants 
Table 2. Education grand rounds topics presented and presenters and college affiliation

\begin{tabular}{|c|c|c|}
\hline Date & Topic & $\begin{array}{l}\text { Presenter college } \\
\text { affiliation }\end{array}$ \\
\hline Jun 2003 & Team-Based Learning & Medicine \\
\hline Jul 2003 & Facilitating Group Discussions & Pharmacy \\
\hline Sep 2003 & $\begin{array}{l}\text { Multigenerational Students: } \\
\text { Strategies for Effective Teaching }\end{array}$ & $\begin{array}{l}\text { Pharmacy (OKC } \\
\text { campus) and Nursing } \\
\text { (Tulsa campus) }\end{array}$ \\
\hline Oct 2003 & $\begin{array}{l}\text { Getting Students Involved in Large } \\
\text { Lectures }\end{array}$ & $\begin{array}{l}\text { Allied Health (OKC and } \\
\text { Tulsa campus) }\end{array}$ \\
\hline Nov 2003 & Adult learner: A Mythical Species & Medicine \\
\hline Jan 2004 & $\begin{array}{l}\text { Enhancing Clinical Teaching Skills } \\
\text { Part I }\end{array}$ & Medicine \\
\hline Feb 2004 & Problem Based Learning (PBL) & $\begin{array}{l}\text { Pharmacy and } \\
\text { Medicine }\end{array}$ \\
\hline Apr 2004 & $\begin{array}{l}\text { Learning Preferences / Myers } \\
\text { Briggs }\end{array}$ & Medicine \\
\hline Jun 2004 & Teaching with Multiple Instructors & $\begin{array}{l}\text { Pharmacy and } \\
\text { Medicine }\end{array}$ \\
\hline Jul 2004 & Web-Supported Teaching & $\begin{array}{l}\text { Allied Health and } \\
\text { Nursing }\end{array}$ \\
\hline Sep 2004 & $\begin{array}{l}\text { Enhancing Clinical Teaching Skills } \\
\text { Part II }\end{array}$ & Medicine \\
\hline Oct 2004 & Professionalism & Medicine (Dean) \\
\hline Nov 2004 & $\begin{array}{l}\text { Improving Your Presentation } \\
\text { Graphics }\end{array}$ & Allied Health \\
\hline Jan 2005 & $\begin{array}{l}\text { Five of the Most Widely Accepted } \\
\text { Methods of Qualitative Research in } \\
\text { Education }\end{array}$ & Medicine \\
\hline Feb 2005 & $\begin{array}{l}\text { Evaluating Your Teaching Using } \\
\text { Self and Peer Evaluation }\end{array}$ & Pharmacy \\
\hline Apr 2005 & $\begin{array}{l}\text { Improved Methods in Team-Based } \\
\text { Learning }\end{array}$ & Medicine \\
\hline May 2005 & Developing an Educator's Portfolio & Medicine \\
\hline June 2005 & Standardized Patients & Medicine \\
\hline July 2005 & Giving Students Feedback & Medicine \\
\hline Sep 2005 & $\begin{array}{l}\text { Improving Your Presentation } \\
\text { Graphics }\end{array}$ & Allied Health \\
\hline Oct 2005 & $\begin{array}{l}\text { Standardized Patients in Clinical } \\
\text { Teaching }\end{array}$ & Medicine \\
\hline Nov 2005 & $\begin{array}{l}\text { Using Objectives as a Learning } \\
\text { Contract }\end{array}$ & Public Health \\
\hline Jan 2006 & Team -Based Learning & Pharmacy \\
\hline Feb 2006 & Blackboard Blackbelt & $\begin{array}{l}\text { Allied Health, Phar- } \\
\text { macy, Nursing }\end{array}$ \\
\hline Apr 2006 & $\begin{array}{l}\text { Virtual Worlds for Educating } \\
\text { Healthcare Providers for Function- } \\
\text { ing Interdisciplinary Teams }\end{array}$ & $\begin{array}{l}\text { Stanford University } \\
\text { School of Medicine - } \\
\text { Medicine }\end{array}$ \\
\hline May 2006 & Educational Scholarship & $\begin{array}{l}\text { Association of Ameri- } \\
\text { can Medical Colleges - } \\
\text { Medicine }\end{array}$ \\
\hline Jun 2006 & $\begin{array}{l}\text { Developing an Educator's Profile, } \\
\text { Portrait, and Portfolio }\end{array}$ & Medicine \\
\hline
\end{tabular}

Dates: September 2006 to June 2007 - Educational research series theme topic

\begin{tabular}{lll}
\hline Sep 2006 & $\begin{array}{l}\text { The Influence of Format for Case } \\
\text { Response on Student Thinking }\end{array}$ & Pharmacy \\
Oct 2006 & $\begin{array}{l}\text { Navigating the Landscape of } \\
\text { Educational Scholarship }\end{array}$ & $\begin{array}{l}\text { Wake Forest } \\
\text { University School of } \\
\text { Medicine }\end{array}$ \\
Nov 2006 & $\begin{array}{l}\text { Best Practices/Suggestions for } \\
\text { Submitting a Good IRB Proposal }\end{array}$ & OUHSC IRB Office \\
\hline
\end{tabular}

Int. J. Medical Education. 2010; 1:30-36
Table 2 continued. Education grand rounds topics presented and presenters and college affiliation

\begin{tabular}{|c|c|c|}
\hline Date & Topic & $\begin{array}{l}\text { Presenter college } \\
\text { affiliation }\end{array}$ \\
\hline Jan 2007 & $\begin{array}{l}\text { Use of an Artificial Intelligence- } \\
\text { Derived, Computer Assisted Tutor } \\
\text { to Teach to and Assess Diagnostic } \\
\text { Competencies }\end{array}$ & $\begin{array}{l}\text { University of North } \\
\text { Texas Health } \\
\text { Sciences Center - } \\
\text { Medicine }\end{array}$ \\
\hline Feb 2007 & Education Scholarship Poster Day & All HSC Colleges \\
\hline Apr 2007 & $\begin{array}{l}\text { Education Grand Rounds Spring } \\
\text { Fling! }\end{array}$ & All HSC Colleges \\
\hline May 2007 & $\begin{array}{l}\text { Education Literature Journal Club } \\
\text { Presentations }\end{array}$ & $\begin{array}{l}\text { Pharmacy and } \\
\text { Medicine }\end{array}$ \\
\hline Jun 2007 & $\begin{array}{l}\text { Education Literature Journal Club } \\
\text { Presentations }\end{array}$ & Pharmacy \\
\hline
\end{tabular}

Dates: September 2007 to June 2008 - The learning frontier theme topic

\begin{tabular}{|c|c|c|}
\hline Sep 2007 & $\begin{array}{l}\text { The Use of Student Reflective } \\
\text { Portfolios in Health Sciences } \\
\text { Education }\end{array}$ & $\begin{array}{l}\text { American Associa- } \\
\text { tion of Colleges of } \\
\text { Pharmacy } \\
\text { (Washington, DC) }\end{array}$ \\
\hline Sep 2007 & Exploring the Learning Frontier & Medicine \\
\hline Oct 2007 & Simulation Programs in Education & Medicine \\
\hline Jan 2008 & $\begin{array}{l}\text { Gold Rush! Avoiding Fools Gold } \\
\text { Competencies in Academic Health } \\
\text { Science Centers }\end{array}$ & $\begin{array}{l}\text { Medicine } \\
\text { (Associate Dean) }\end{array}$ \\
\hline Feb 2008 & $\begin{array}{l}\text { Staking Your Claim Through } \\
\text { Educational Research }\end{array}$ & Public Health \\
\hline Apr 2008 & $\begin{array}{l}\text { Leadership on the Educational } \\
\text { Frontier: Roadmaps \& Detours }\end{array}$ & $\begin{array}{l}\text { Pharmacy } \\
\text { (Dean) }\end{array}$ \\
\hline May 2008 & $\begin{array}{l}\text { Organizing a Barn Raising: Creating } \\
\text { a Significant Learning Experience }\end{array}$ & $\begin{array}{l}\text { OU Norman - Arts } \\
\text { and Sciences }\end{array}$ \\
\hline Jun 2008 & $\begin{array}{l}\text { Bridges into Higher Level Learning. } \\
\text { Designing Instruction to Move } \\
\text { Learners from Comprehension to } \\
\text { Application }\end{array}$ & Allied Health \\
\hline
\end{tabular}

reported their satisfaction with the EGR sessions as above or significantly above average. On average, $74.17 \%$ (range $=68$ - 82.67) of participants reported that they learned an above or significantly above average amount of information at the EGR sessions. For the needs assessment question, attendees rarely indicated topical preferences for future EGR sessions.

\section{Conclusions}

\section{Objective 1}

Data collected over five years reveal that EGR was consistently delivered to all colleges and both campuses at our AHC at least eight months a year and the majority of sessions each year reflected the six prioritized education topics. While the interdisciplinary nature of the EGR program is a strength, providing effective education for interdisciplinary audiences is challenging. ${ }^{10}$ One metaanalysis revealed that presentations designed for a single audience (all obstetricians) are associated with better outcomes which may be due to more focused and relevant presentation materials. ${ }^{11}$ Anecdotally, the presenter's 
discipline positively influenced the number of attendees from that discipline. In fact, for the EGR planning team, some disciplines were more active in planning, which may have influenced faculty perceptions of low relevance and low attendance from the underrepresented disciplines.

Table 3. Education grand rounds presenters (interdisciplinary, national, distance)

\begin{tabular}{cccc}
\hline $\begin{array}{c}\text { Distant campus } \\
\text { presenter }\end{array}$ & $\begin{array}{c}\text { Interdisciplinary } \\
\text { team presenters }\end{array}$ & $\begin{array}{c}\text { National } \\
\text { presenter }\end{array}$ & $\begin{array}{c}\text { Dean/admin } \\
\text { presenters }\end{array}$ \\
\hline 4 & 7 & 6 & 14 \\
\hline
\end{tabular}

These results may suggest that EGR move from a centralized to college specific development program to improve learning outcomes; however, the meta-analysis study reviewed results from continuing medical education which may be more discipline specific compared to teaching topics program which may be more broadly applicable to a diverse audience. Future EGR sessions should specifically evaluate attendee's perceptions and learning outcomes of topics presented outside his/her discipline in order to better guide programming.

Table 4. Education grand rounds presenters (disciplines)

\begin{tabular}{cccccccc}
\hline \multicolumn{2}{c}{ Medicine Pharmacy Nursing } & $\begin{array}{c}\text { Allied Public } \\
\text { health health }\end{array}$ & Dentistry & $\begin{array}{c}\text { Physician } \\
\text { assistant affiliation }\end{array}$ \\
\hline 27 & 13 & 3 & 6 & 2 & 0 & 0 & 2 \\
\hline
\end{tabular}

Results reveal that the EGR team designed programming around six prioritized topics, but developing the topics was challenging because the audience did not document their needs for future programming on the anonymous session evaluations collected at the end of each EGR session. Using the six topics as framework did promote intentional sequencing of topics. Programming would be enhanced if faculty indicated to the EGR team their faculty development needs like they do during annual review or in programs that use continuous professional development models. ${ }^{12}$ This shift would help faculty be more proactive in seeking development and could allow the team to meet documented needs. The literature also recommends benchmarking as a tool for assessing needs, which may be a viable option on our AHC since it does offer campus wide teaching awards, offering performance standards for top educators. ${ }^{12}$ Faculty members could evaluate themselves against the teaching award winners, set goals for improvement and identify EGR sessions that could help them achieve their goals. Overall, methods for better identifying faculty development needs should be explored further by the EGR team.

\section{Objective 2}

The results reveal Objective 2 was achieved and a variety of disciplines on both campuses were represented by the presenters. National speakers also presented at EGR offering attendees discussion of new education techniques, practices, and perspectives. The results related to local and national presenters do reveal that the majority of local and national presenters were from the college of medicine. One limitation of EGR is that the impact of discipline specific presenters on attendees' knowledge, skill or attitude outcomes was not assessed. Therefore, current data do not enable us to assess whether the majority of medicine presenters had any influence on audience outcomes. Future studies should evaluate the impact of local versus national presenters and main versus distant campus presenters on attendance rates and participant learning outcomes.

\section{Objective 3}

In addition to regular programming offered to the HSC campus on six education topics, the attendance results suggest EGR increased the interdisciplinary dialogue about education on campus. Offering EGR regularly was an important objective to accomplish because the EGR team wanted to establish it as a resource and sporadic offerings could decrease the reliance on EGR as a development tool.

However, the limitation of this outcome is that the team has not formally assessed if attendees view EGR as an established faculty development resource. Related to this objective, the regular offerings were aimed at increasing the importance of teaching on campus and reduce the isolation associated with teaching. These outcomes will be formally assessed in the future to better document programmatic outcomes.

One endpoint of Objective 3 was attendance and as Table 5 reveals, overall attendance at the sessions was on average 20 or less at the main campus site, and attendance by members of each of the disciplines was similarly low. While a small group in attendance is beneficial for active learning and audience and speaker interaction, a larger audience would indicate that the program is reaching and potentially informing a larger number of faculty. There are possible reasons for the low attendance. One reason is that at an AHC there are no designated "free times" for faculty to attend development programs due to the variability in faculty clinic, research and teaching schedules. For example, some faculty have clinic over the noon hour and that clinic time may vary over the months. In fact, for the past five years EGR was held from 11 am to 12 noon on Friday mornings due to room availability. The EGR team recognized that this schedule may conflict with many clinical faculty's patient responsibilities in the morning. As a result, in 2008 EGR moved to 12 to $1 \mathrm{pm}$ on Fridays with the hope that the new time would increase attendance and it has, but the faculty lack of free time blocks still present a problem.

A second reason for low attendance at this one-hour program may be the necessity of travel to the auditorium site. As noted, a decision was made by the EGR team early in planning to post programs after the live offering rather than synchronously. With the introduction and piloting of MediaSite technology the option to deliver programs in synchronous live and web-view may be reconsidered. Although attendance was nominal, there was consistent 
attendance from all of the colleges at EGR and those attendees may be returning to their colleges and sharing what was learned at the sessions, thus extending the outreach of EGR. Outreach is also accomplished by the availability of EGR session materials on the web. Options for increasing attendance will be included in future program outcome assessments.

Table 5. Average college faculty monthly attendance at education grand rounds from September 2006 to June 2008 from both Oklahoma City and Tulsa campuses combined

\begin{tabular}{lcccccc}
\hline \multirow{2}{*}{ College } & \multicolumn{2}{c}{ Average } & \multicolumn{2}{c}{ Range high } & \multicolumn{2}{r}{ Range low } \\
& $06-07$ & $07-08$ & $06-07$ & $07-08$ & $06-07$ & $07-08$ \\
\hline Medicine & 8 & 5 & 16 & 11 & 2 & 2 \\
Pharmacy & 4 & 7 & 10 & 19 & 2 & 2 \\
Nursing & 2 & 3 & 5 & 7 & 1 & 1 \\
Allied health & 2 & 2 & 2 & 4 & 1 & 1 \\
Public health & 2 & 2 & 4 & 3 & 1 & 1 \\
Dentistry & 2 & 2 & 3 & 3 & 1 & 1 \\
Physician assistant & 0 & 0 & 0 & 0 & 0 & 0 \\
Academic technology & 2 & 1 & 4 & 2 & 1 & 1 \\
Provost office & 2 & 2 & 1 & 2 & 1 & 2 \\
Grad college & 0 & 1 & 0 & 1 & 0 & 1 \\
Other affiliation & 0 & 4 & 0 & 1 & 0 & 7 \\
\hline
\end{tabular}

Attendance has also been a concern at the distant campus, because it has been difficult to increase attendance and engage attendees at the distant site. This means that the conversations held between campuses and within the distant campus are more variable. Future directions proposed for consideration by the EGR team include having more distant site faculty presenters to stimulate attendance and conversations between campuses and among the distance site. Perceptions of involvement of distant site participants need to be explored further in future studies. Faculty have reported on EGR session evaluations that they are satisfied with the sessions and that they perceive gaining knowledge and/or skills about the education topics emphasized. These results may be due to the programming which is aimed at covering practical versus theoretical topics, which traditionally receive higher ratings from faculty. ${ }^{13}$ The selected topics are aimed at both clinicians and basic scientists, but the majority of presentations focused on didactic teaching, education technology and education scholarship/research, whereas fewer presentations emphasized clinical teaching topics. Since EGR is designed for faculty teaching at an AHC where many faculty have clinical teaching responsibilities, offering more clinical teaching programming may increase the outreach and effectiveness of the program. Overall, the need for more clinical sessions and the outcome of sessions should be explored in future studies of EGR to determine how to better meet the needs of faculty and to how faculty have used the knowledge, skills or attitudes learned from the sessions in their teaching.

The literature does suggest that programs that use two or more education strategies can lead to change in practice. ${ }^{12}$ As the study results show, two additional modalities were offered to participants, education scholarship day and journal clubs. The education scholarship day had higher attendance then the journal clubs and offered insight into the ability of faculty to present the scholarship of teaching and educational research as a result of presentations in these two areas. Therefore the use of sequenced sessions presented in multiple modalities should be explored and assessed more formally in the future.

Overall, the results for Objective 3 reveal the potential benefit of more flexible faculty development that is asynchronous and on-demand. As Table 6 reveals, the archived EGR sessions are viewed by faculty and faculty watch a majority of the program. Future EGR plans focus on identifying a core of foundational teaching topics from the EGR archived presentations, reviewing the quality of those presentations for asynchronous use and then creating a teaching certificate program for faculty creating advanced tracks as well. This certificate program would address the benefits of sequencing and meeting specific faculty development needs. Studies of this modality would need to address the ability of the online sessions to promote and ensure that the faculty are participating in the active learning and benefiting from the interaction since the sessions would be viewed independently.

\section{Objective 4}

The active learning presenter guidelines has influenced the formatting of all of the presentations to dedicate time to active learning, although data have not been formally collected on the types that are most well received, the audience's satisfaction with the amount of active learning or the long term active learning outcomes. Future programming guidelines will require the first 15-20 minutes of the session to utilize direct instruction to allow for better production of the session as a learning tool for faculty who can't attend the live session but plan to watch it online, because the concentrated timeframe should better accommodate faculty availability for asynchronous development. Future studies should then methodically document the types of active learning employed and the impact of active learning on teaching improvement or change. It may be possible to include student perceptions of change and student learning outcomes, since many continuing education program outcomes focus on patient improvement.

In summary, EGR is a sustainable form of faculty development focused on teaching for faculty at an AHC with a multi-disciplinary and multi-campus environment. Future efforts should formally focus on assessing the impact on attendees' perceptions of learning and actual learning 
outcomes as a result of multi-disciplinary presenters, local versus national presenters, multiple modalities of the same or sequenced topics, amount and type of active learning used, asynchronous viewing options, and teaching certificate programs. Identifying faculty development needs and attendance barriers should also be reviewed.

Table 6. Number of faculty viewing archived EGR presentations from the desktop or EGR website from Jan 2008 to May 2008

\begin{tabular}{|c|c|c|c|c|}
\hline Date & Topic & $\begin{array}{l}\text { Live view } \\
\text { from desktop } \\
\text { using media } \\
\text { site }\end{array}$ & $\begin{array}{l}\text { On demand } \\
\text { views } \\
\text { from EGR } \\
\text { website }\end{array}$ & $\begin{array}{l}\text { Average } \% \\
\text { of entire } \\
\text { presentation } \\
\text { watched }\end{array}$ \\
\hline Sep 2007 & $\begin{array}{l}\text { Exploring the } \\
\text { Learning Frontier }\end{array}$ & 0 & 46 & 50 \\
\hline Oct 2007 & $\begin{array}{l}\text { Simulation } \\
\text { Programs in } \\
\text { Education }\end{array}$ & 1 & 17 & 67 \\
\hline Jan 2008 & $\begin{array}{l}\text { Gold Rush! } \\
\text { Avoiding Fools } \\
\text { Gold Competen- } \\
\text { cies in Academic } \\
\text { Health Science } \\
\text { Centers }\end{array}$ & 0 & 48 & 67 \\
\hline Feb 2008 & $\begin{array}{l}\text { Staking Your Claim } \\
\text { Through Educa- } \\
\text { tional Research }\end{array}$ & 1 & 20 & 35 \\
\hline Apr 2008 & $\begin{array}{l}\text { Leadership on the } \\
\text { Educational } \\
\text { Frontier: Road- } \\
\text { maps \& Detours }\end{array}$ & 2 & 26 & 34 \\
\hline May 2008 & $\begin{array}{l}\text { Organizing a Barn } \\
\text { Raising: Creating a } \\
\text { Significant } \\
\text { Learning Expe- } \\
\text { rience }\end{array}$ & 4 & 96 & 86 \\
\hline \multirow[t]{2}{*}{ Jun 2008} & $\begin{array}{l}\text { Bridges into Higher } \\
\text { Level Learning. } \\
\text { Designing } \\
\text { Instruction to Move } \\
\text { Learners from } \\
\text { Comprehension to } \\
\text { Application }\end{array}$ & 0 & 24 & 50 \\
\hline & Average Views & 1.1 & 39.6 & 56 \\
\hline
\end{tabular}

\section{Acknowledgments}

We gratefully acknowledge the members of the Provost's Office, Education Grand Rounds advisory team, and the TV services staff for their meaningful contributions to EGR.

\section{References}

1. Steinert Y, Mann K, Centeno A, Dolmans D, Spencer J, Gelula M, Prideaux D. A systematic review of faculty development initiatives designed to improve teaching effectiveness in medical education. Med Teach. 2006;28:497-526.

2. Cole KA, Barker LR, Kolodner K, Williamson P, Wright SM, Kern DE. Faculty development in teaching skills: an intensive longitudinal model. Acad Med. 2004;79:469-480. 3. Wilkerson L, Irby DM. Strategies for improving teaching practices: a comprehensive approach to faculty development. Acad Med. 1998;73:387-96.

4. Banta TW. Can assessment for accountability complement assessment for improvement? Peer Review. 2007;9: 912.

5. Reder M. Does your college really support teaching and learning? Peer Review. 2007;9: 9-13.

6. Knight AM, Cole KA, Kern DE, Barker LR, Kolodner K, Wright SM. Long-term follow-up of a longitudinal faculty development program in teaching skills. J Gen Intern Med. 2005;20:721-725.

7. Clark JM, Houston TK, Kolodner K, Branch WT, Levine RB, Kern DE. Teaching the teachers: national survey of faculty development in departments of medicine of US teaching hospitals. J Gen Intern Med. 2004;19:205-14.

8. Hebert RS, \& Wright SM. Re-examining the value of medical grand rounds. Acad Med. 2003;78:1248-52.

9. Stagnaro-Green A. Medical education grand rounds. Acad Med. 1995;70:429-30.

10. Greiner AC, Knebel E. Health Professions Education: A Bridge to Quality. Washington, DC: National Academies Press; 2003.

11. Mansouri M, Lockyer J. A meta-analysis of continuing medical education effectiveness. J Contin Educ Health Prof. 2007;27:6-15.

12. Mazmanian PE, Davis DA. Continuing medical education and the physician as a learner: guide to the evidence. JAMA. 2002;288:1057-1060.

13. Sheets KJ. Evaluating short-term training programs: a practical approach. Journal of Instructional Development. 1985;8:26-32. 